\title{
RESPONSE
}

\section{A Dysfunctional Worldview}

\author{
Paul Gifford
}

The great virtue of this study by Priest, Ngolo, and Stabell (henceforth simply Priest et al.) is that it reveals in all its starkness the enchanted imaginaire of Kinshasa's revivalist pastors-their determination to seek spiritual causality for this-worldly occurrences. I know there is a debate about situating this imaginaire, of linking it to a particular form of Christianity. Since, not least for brevity, we must use labels, I will call this mindset 'Pentecostal' (admitting that Priest's label 'revivalist' is perhaps less contentious, because it allows us to avoid debates bearing on the origins and nature of classical Western Pentecostalism). I am well aware that there exist Pentecostal churches that explicitly repudiate this mindset, but I am satisfied that they are a negligible minority. I am also convinced that the greatest single reason for what is called Africa's 'Pentecostal explosion' is that a form of Christianity has arisen that allows full play to this enchanted mindset, something the mainline churches were historically very reluctant to do. Priest at al. well show that this mindset is found more widely-the study includes Independents, mainline Protestants and Catholics-and shows (with the sampling limitations they outline) that the outlook of all is quite similar, thereby also illustrating the phenomenon called the 'Pentecostalisation' of the mainline churches.

Why is it important to flag up this Pentecostal (or revivalist) worldview? Because for many observers it is almost axiomatic that African Pentecostalism is a major vehicle of modernity. For the late Peter Berger, the spread of Pentecostalism is probably the best thing to happen to the developing world. With its stress on motivation, entrepreneurship and discipline, this is the Protestant work ethic reaching the third world. It will do for the developing world what some say Calvinism did for Europe in the $18^{\text {th }}$ century.

In 2008, South Africa's Centre for Development and Enterprise, heavily influenced by Berger, produced a report on Pentecostalism entitled Under the Radar which makes great claims for the public effects of Pentecostalism. The report is influenced by 'the claims of sociologists of religion that Pentecostalism has a special affinity with market-based development, and a kinship with what historians call the "Protestant ethic"; a cluster of beliefs, attitudes and habits that underpinned the spectacular economic growth of north-west Europe during the industrial revolution' (Centre for Development and Enterprise 2008, 9). Encouraging entrepreneurship is considered the main characteristic, so much so that the report actually urges the South African state to promote Pentecostalism in the cause of the country's development (34).

David Martin has spelt this out fully: 'The lineage running from Pietism to Pentecostalism is linked positively to modernity in respect of the domains of gender, secular law, transnationalism, voluntarism, pluralism, the nuclear family, peaceability, personal release and personal work discipline, consumption, modern communication, social and geographical mobility -as well as changes in mediation, authority, and participation' $(2005,144)$. In other words, in all these areas, from gender to law, from work ethic to exercise of authority, Pentecostalism is bringing Africa into the modern world.

I think these positive assessments require that one focus only on motivation, entrepreneurship and personal life skills (which I readily admit are prominent in many of these churches). If one considers only them, the effects must of course be positive. But these positive evaluations hardly advert to the underlying world-view which Priest et al. lay bare so starkly here, and which I regard as much more significant. To the extent that African churches build on this enchanted worldview, the effects seem far less positive.

Many readers will know of JDY Peel. Peel, as well as being a personal friend and mentor, was an anthropologist of considerable repute-he won the Herskovits Prize, the award given by the African Studies Association for the best scholarly work on Africa published in English the previous year, and he won it not only once but twice, a feat only one other scholar has equaled. Already diagnosed with the cancer that would kill him in 2015 but as alert as ever, Peel spent many months of several of his last years in the Robertsport area of Liberia where his wife was promoting human rights with the United Nations Mission in Liberia (UNMIL). During these visits he would send 'Letters from Liberia' to a group of seven or eight friends. The letters tell of accompanying his wife on her duties, not the least of which was to attend witch-finding sessions where her task was essentially to monitor ('without intervening in local cultural activities') 
that no illegal force or violence was employed. Peel describes these occasions with admirable academic objectivity, but after recounting one witch-finding session in which 22 villagers had confessed to being witches and the village had managed to reduce the community's witch-cleansing fee to US\$200, Peel's academic objectivity fails him. He writes that these recurrent witch-finding procedures '(drive) away most of my anthropological relativism and (make) me feel like a missionary: "O may the Lord open their eyes" . - What is more depressing: the humiliation of these wretched souls by their neighbours and kinsfolk for their absurd supposed misdeeds, or the spectacle of poor people in a poor community blaming themselves for their poverty, with the connivance of a state that preaches development at them?'

Not the least interesting point of Peel's outburst is his assumption that a missionary would take a less neutral stance than an anthropologist towards such witchfinding. However, Christians of any sort are today very reluctant to fault any aspect of African culture, for African culture has become something sacrosanct. It is quite understandable why this should be so. As Paul Bowers has argued, the most traumatic event in the history of Africa was its encounter with the West, which led not only to a loss of political control but also to a damaged self-understanding. As a result, since Independence the dominant preoccupation in all African intellectual life has been resistance to continued Western economic and intellectual hegemony, and the affirmation of African identity and authenticity vis-à-vis the West, especially by affirming its identity with Africa's traditional heritage (Bowers 2002, 109-25). African culture has become a non-negotiable pivot around which much African theologizing turns, most evident in the (predominantly Catholic) project of 'inculturation', and given a recent expression in Agbonkhianmeghe Orobator's Religion and Faith in Africa: Confessions of an Animist (2018). There is much of value in this book, as one would expect from a former Jesuit Provincial of East Africa, but glorying in a mindset that finds spiritual forces pervasive is not without hazards: the same mindset that leads to preserving groves of trees is the very mindset that leads to identifying children as witches.

The study by Priest et al. does more than simply spell out how this enchanted worldview has led several pastors in Kinshasa to identify waifs as witches. It has raised a much bigger issue. I have recently argued that in the last few centuries a new consciousness has arisen which has peripheralised seeking causes for this-worldly events in the spirit world, and has developed a repertoire of causes on another plane altogether. This new consciousness has not disproved the existence of these spiritual forces, nor the possibility of their activity, but it has peripheralised them as responsible for thisworldly situations and events. This cognitive style of analysing objects and events on a mundane level of causality has given us air travel, computers and antibiotics (it has also given us nuclear warheads and acid rain, but here I am concerned with accepting the reality rather than highlighting its challenges). This new consciousness (which of course has raised all sorts of novel-and serious-questions for Christian theology) is almost the definition of 'modernity' (Gifford 2019). Yet the churches studied here perpetuate a world-view holding Africa back; they are among the powerful mechanisms preventing Africa from taking its rightful place in the modern world. Thus the conclusion of David Martin's study: 'Pentecostalism in Africa is a collective raft pointed with determination towards modernity' $(2002,152)$, must be considered profoundly mistaken. It is the huge benefit of this study by Priest et al. that it helps make the dysfunctionality of this worldview inescapable.

The other point I would raise is the relationship between the Bible and this enchanted imaginaire. Priest, as one who 'accept(s) the authority of scripture', suggests that these pastors may have 'fundamentally misread their Bibles', and gives considerable attention (of immense sophistication) to the translation of individual Bible passages. I would by contrast argue that this enchanted worldview is not so narrowly a matter of biblical interpretation, much less of interpretation of particular passages. Consider the Deliverance Bible of the Nigerian Daniel Olukoya, the founder (in 1989) and head of the Mountain of Fire and Miracles Ministries. The church claims that its regular Sunday attendance at headquarters gives it the largest single Christian congregation in Africa (a 2012 church magazine gives the figure as 200,000). It has spread widely, even outside Africa; the same magazine lists 83 branches in Britain (Monthly Miracle 2012, 21-23). For Olukoya the entire Bible is concerned with witches, demons, spells and curses. It is not that particular texts (even key texts) lead him to the view that witchcraft is operative everywhere. Already convinced of this worldview, he turns to the Bible and finds this understanding throughout. Olukoya singles out 35 texts which as it were encapsulate the message of the Bible. These are texts like Gen 15,16; 49,1-7; Ex 2,1-9; Jer 7,$18 ; 44,17 ; 44,19-$ it is unnecessary to go on, except to note that for most of us these hardly lead to Olukoya's

Of course, as with so many such statistics, these are calculated to impress as much as to convey data. 
convictions at all. ${ }^{2}$ Clearly, Olukoya is not deriving his position from the Bible, but reading his prior convictions into the Bible. If, like Okukoya, one is determined to find this worldview in the Bible, one obviously can. A better translation of particular texts would hardly affect this.

\section{References}

Bowers, Paul. 2002. African Theology: Its History, Dynamics, Scope and Future. Africa Journal of Evangelical Theology 21(2):109-25.

Centre for Development and Enterprise. 2008. Under the Radar: Pentecostalism in South Africa and its Potential Social and Economic Role. CDE In Depth 7:9.

Gifford, Paul. 2015. A contemporary Nigerian Reading of the Bible. Journal of Theology for Southern Africa 152:38-56.

- 2019. The Plight of Western Religion: The Eclipse of the Otherworldly. London: Hurst \& Co; New York: OUP.

Martin, David. 2002. Pentecostalism: The World their Parish, Oxford: Blackwell.

- 2005. Pentecostalism: a Major Narrative of Modernity. In On Secularisation: Towards a Revised General Theory. London: Ashgate.

Monthly Miracle, May 2012, 21-23.

Orobator, Agbonkhianmeghe. 2018. Religion and Faith in Africa: Confessions of an Animist. Maryknoll: Orbis.

Priest, Robert J., Abel Ngolo and Timothy Stabell. 2020. Christian Pastors and Alleged Child Witches in Kinshasa, DRC. On Knowing Humanity Journal 4(1):1-51.

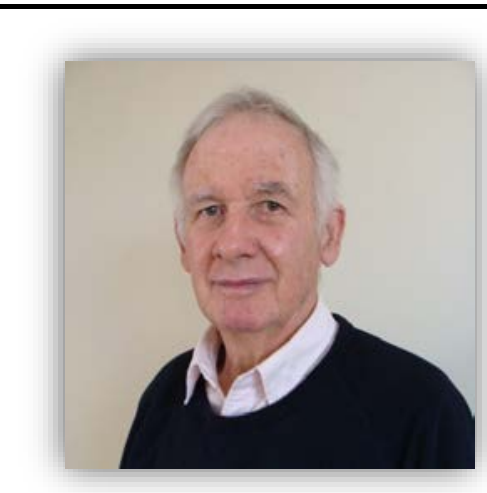

Paul Gifford is Emeritus Professor of Religion at SOAS University of London, and author of many books on Christianity in Africa'.

Author email: pg@soas.ac.uk

\footnotetext{
${ }^{2}$ For detailed analysis of the issues here, see Paul Gifford, 'A contemporary Nigerian Reading of the Bible', Journal of Theology for Southern Africa, 152 (2015), 38-56.
} 